\title{
A szégyen mediációs szerepe a stigma és az életminőség kapcsolatában coeliakiában szenvedő betegek körében
}

\author{
A 8 tételes Stigmatizáció Krónikus Betegségekben Kérdőin \\ magyar adaptálása
}

\author{
Szőcs Henrietta ${ }^{1,2}$. Horváth Zsolt ${ }^{1,2}$ - Vizin Gabriella dr. ${ }^{2,3}$ \\ ${ }^{1}$ Eötvös Loránd Tudományegyetem, Pedagógiai és Pszichológiai Kar, Pszichológiai Doktori Iskola, Budapest \\ ${ }^{2}$ Eötvös Loránd Tudományegyetem, Pedagógiai és Pszichológiai Kar, Pszichológiai Intézet, Budapest \\ ${ }^{3}$ Semmelweis Egyetem, Általános Orvostudományi Kar, Klinikai Pszichológia Tanszék, Budapest
}

\begin{abstract}
Bevezetés: A coeliakia és a kapcsolódó terhek befolyásolják az érintettek életminőségét. A krónikus betegségekkel járó stigmatizáció hozzájárul a fizikai tünetek és a lelki panaszok fokozódásához, valamint az egészségmagatartás csökkenéséhez. Mindez szükségessé teszi a krónikus megbetegedések kapcsán a stigmatizáció felismerését, felmérését és kezelését.

Célkitüzések: Fő célunk a 8 tételes Stigmatizáció Krónikus Betegségekben Kérdőív (SSCI-8) magyar adaptációja és pszichometriai vizsgálata volt coeliakiások körében. További célunk volt megvizsgálni a szégyen közvetítő szerepét a stigmatizáció és a jóllét között.

Módszerek: A kutatás önbeszámolós, online kérdőíves, keresztmetszeti vizsgálatként zajlott $(\mathrm{n}=85$, átlagéletkor: 37,64, 91,8\% nő). Az SSCI-8 mellett felvételre kerültek a szégyenélményt, a coeliakiás életminőséget, a jóllétet mérő kérdőívek. A kutatási célok tesztelése megerősítő faktorelemzéssel, korrelációs és mediációs elemzésekkel történt.

Eredmények: Az SSCI-8 faktorelemzése során az egydimenziós modell megfelelő illeszkedést mutatott magas belső konzisztenciaértékek mellett. A mediációs modellek szerint a magasabb stigmatizáció a magasabb szégyenélményen keresztül járulhat hozzá a pszichés jóllét (coeliakiás életminőség, jóllét) csökkenéséhez.

Megbeszélés: Az SSCI-8 rövid, átfogó kérdőívként megbízhatóan és érvényesen mérte a krónikus betegségben tapasztalt stigmatizációt a jelen coeliakiás mintán. Eredményeink alátámasztják, hogy a stigmatizáció és a szégyen fontos szerepet tölt be a jóllét csökkenésében.

Következtetés: A nemzetközileg széles körben alkalmazott SSCI-8 adaptálására került sor, mely hazai kutatásokban és az egészségügyi ellátásban is hasznos mérőeszköz lehet. Az eredmények rávilágítanak, hogy a stigmatizáció és a szégyenélmény további kutatása szükséges, különösen a hatékony pszichoszociális intervenciók kifejlesztését megcélozva. Hatékony pszichológiai segítség révén a szégyen és a stigmatizáltság mérséklésével javulhat a coeliakiával élők fizikai és lelki állapota, ami a gluténmentes diéta betartása révén hozzájárulhat a betegség okozta tünetek és szövődmények mérsékléséhez.
\end{abstract}

Orv Hetil. 2021; 162(49): 1968-1976.

Kulcsszavak: stigmatizáció, coeliakia, szégyen, jóllét, életminőség

\section{Shame mediates the relationship between stigma and quality of life among patients with coeliac disease}

\section{The Hungarian adaptation of the Stigma Scale for Chronic Illness-8}

Introduction: Coeliac disease can detrimentally affect well-being. Stigmatization related to a chronic disease can enhance physical and psychological symptoms and negatively influence health behaviour, hence, stigma in chronic diseases needs to be addressed.

Objectives: Our main goal was to psychometrically evaluate the Hungarian adaptation of the Stigma Scale for Chronic Illness-8 (SSCI-8). Further aim was to examine the mediating role of shame on the relationship between stigmatization and well-being aspects among individuals with coeliac disease. 
Methods: This cross-sectional study collected data using online questionnaires based on self-reports $(\mathrm{n}=85$, mean age: 37.64 years, $91.8 \%$ women). Instruments assessed levels of stigmatization, shame experience, quality of life in coeliac disease and well-being. Confirmatory factor, correlation and mediation analyses were used.

Results: Factor analysis showed adequate fit for a unidimensional model with high internal consistency. Mediation models showed that higher levels of stigmatization can contribute to decreased levels of quality of life in coeliac disease and well-being via increased levels of shame.

Discussion: The SSCI-8 is a short, valid, reliable instrument measuring stigmatization in the current sample of people with coeliac disease. The results highlight the role of stigma and shame in the decrease of well-being.

Conclusion: The adapted version of the SSCI- 8 can be a useful tool in Hungarian research and healthcare. The results suggest that stigmatization and shame need further attention to develop effective intervention which can reduce their effect and enhance adherence to gluten-free diet and improve physical and psychological well-being.

Keywords: stigma, coeliac disease, shame, well-being, quality of life

Szőcs H, Horváth Zs, Vizin G. [Shame mediates the relationship between stigma and quality of life among patients with coeliac disease. The Hungarian adaptation of the Stigma Scale for Chronic Illness-8]. Orv Hetil. 2021; 162(49): 1968-1976.

(Beérkezett: 2021. március 23.; elfogadva: 2021. május 25.)

\begin{abstract}
Rövidítések
$\mathrm{CDQ}=($ Coeliac Disease Questionnaire $)$ Coeliakia Életminőség Kérdő́iv; CFI = (comparative fit index $)$ komparatív illeszkedési mutató; $\mathrm{CI}=$ (confidence interval) konfidenciaintervallum; CIASS $=($ Chronic Illness Anticipated Stigma Scale $)$ Krónikus Betegségekben Anticipált Stigma Skála; COVID-19 $=$ (coronavirus disease 2019) koronavírus-betegség 2019; ELTE PPK = Eötvös Loránd Tudományegyetem, Pedagógiai és Pszichológiai Kar; ESS = (Experience of Shame Scale) Szégyen Élmény Skála; GFD = (gluten-free diet) gluténmentes étrend; GRD = (gluten-related disorder) gluténnel kapcsolatos rendellenesség; GMÉ = gluténmentes étrend; HIV = (human immunodeficiency virus) emberi immunhiányt előidéző vírus; MLR $=$ (maximum likelihood robust to non-normality) a maximum likelihood becslési eljárás normalitástól való eltérésre robusztus változata; RMSEA = (root mean square error of approximation) residuumok átlagos négyzetgyöke; SRMR = (standardized root mean square residual) standardizált residualis négyzetes középérték; SSCI-8 = (8-item Stigma Scale for Chronic Illness) 8 tételes Stigmatizáció Krónikus Betegségekben Kérdőív; tbc = tuberkulózis; TLI = Tucker-Lewis Index; $\mathrm{WBI}=($ WHO Well-Being Index $)$ WHO Jóllét Kérdőív
\end{abstract}

Szomatikus és pszichés megbetegedésekben egyaránt gyakori jelenség a stigmatizáció [1]. Különösen igaz ez krónikus megbetegedések esetén, amelyek további testi és lelki terheket rónak a betegséggel küzdő személyekre [2]. Empirikus kutatások eredményei szerint a stigmatizáció a fizikai tünetek és a lelki panaszok megjelenésének fokozódását, valamint az egészségmagatartás csökkenését vonja maga után [3].

A stigmatizáció egy attribútum, egy fizikai vagy szociális jegy/jel megjelenéséből fakad (például ritka testi jellegzetesség, testi vagy szellemi fogyatékosság, testi vagy mentális megbetegedés), amelyet mások nem képesek teljesen elfogadni, leértékelik, ami magában hordozza az adott személy vagy személyek szociális identitását is [4].
Ezt a társadalom által közvetített rosszallást a klasszikus stigmakoncepció externális (enacted) stigmaként különíti el. A negatív reakciók következtében az érintett személyben kialakul a tapasztalatból fakadó, kisebbrendúségre vonatkozó következtetés, internalizálódik a negatív stigma, melyet internalizált (internalized) stigmának nevezünk [4]. Modernebb elméletek a jelenség kognitív, érzelmi és viselkedéses aspektusait hangsúlyozva elkülönítenek észlelt, anticipált és internalizált stigmát $[5,6]$. Az észlelt stigma a stigmatizált személy benyomására vonatkozik arról, hogy mások hogyan viszonyulnak hozzá [7], míg az anticipált stigma az érintett személy jövőbeli, stigmatizáltsággal kapcsolatos tapasztalatairól szóló elvárásait jelenti [3].

Krónikus betegséggel küzdőknél maga a betegség bizonyulhat olyan attribútumnak, amely kapcsán stigmatizációt élhetnek meg a személyek [1]. A stigmatizáció előfordulása összefüggést mutat a betegség látványosságával/nyilvánvalóságával [8]. Kevésbé feltűnő betegségekkel rendelkező személyek kevésbé lehetnek stigmatizáltságnak kitéve, az egyes tüneteket viszont nem lehet mindig elrejteni, és amint felszínre kerülnek, megjelenik a stigma is [8]. Miután a népesség közel $40 \%$-a küzd valamilyen krónikus megbetegedéssel [9], feltételezhető, hogy az ezekhez kapcsolt stigmatizáció negatív következményei népegészségügyi kockázatot jelenthetnek. Mindez szükségessé teszi a krónikus megbetegedések kapcsán a stigmatizáció felismerését és felmérését. Jelenleg két rövid stigmatizáció-kérdőív áll rendelkezésünkre, a Krónikus Betegségekben Anticipált Stigma Skála (Chronic Illness Anticipated Stigma Scale - CIASS; [3]), valamint a 8 tételes Stigmatizáció Krónikus Betegségekben Kérdőív (Stigma Scale for Chronic Illness - 8, SSCI8; [10-12]). A CIASS [3] a stigmatizáció felmérésének 12 tételes, megbízható mérőeszköze, azonban csupán az egyik stigmatizációfaktor, az ún. anticipált stigma felmé- 
résére alkalmas mérőeszköz. Az SSCI-8 egy rövidebb, mégis átfogó mérőeszköz: 8 tételes kérdőív, amelynek tételei leírnak internatizált és externális stigmatizációs jellemzőket egyaránt [13]. Az SSCI-8-at eredetileg neurológiai betegségekkel kapcsolatos stigmatizáció mérésére fejlesztették ki, de egyéb krónikus betegségekkel (például krónikus fájdalom, rosszindulatú emlődaganat) végzett kutatások alapján más megbetegedések esetén is valid és reliábilis mérőeszköz [10, 12-15]. Jelenlegi tudásunk szerint az SSCI-8 hazai adaptációja még nem történt meg.

A stigmatizációval kapcsolatban leggyakrabban kutatott krónikus megbetegedések a HIV, a tbc, a mentális zavarok, az epilepszia és a szerhasználati zavarok [1, 6, 16]. A coeliakiával kapcsolatban is egyre több vizsgálati eredmény áll rendelkezésünkre [17-19]. A coeliakia a genetikailag kitett személyek vékonybeleiben gluténfogyasztásra létrejövő krónikus, immunmediált enteropátia [20]. A glutén a kenyérféléken és péksüteményeken túl az élelmiszerek széles körében fellelhető [21]. Jelenleg több, gluténhoz köthető zavart és intoleranciát tartunk számon (gluten-related disorders, GRDs) [22], melyek gyakorisága 5\%-ra tehető [23]. A GRD-k között megkülönböztetünk allergiás (búzaallergia), autoimmun (coeliakia, dermatitis herpetiformis, glutenataxia) és valószínúsíthetőleg immunmediált változatot (nem coeliakiás gluténérzékenység) [22]. Ezek közül a leggyakoribb zavar a gluténszenzitív enteropátia, más néven coeliakia [24]. Gyakorisága országonként változó; hazánk lakosságának 1,5-2\%-át érintheti a megbetegedés [25], és háromszor gyakoribb nőknél, mint férfiak körében [26]. A megbetegedés gyakorisága világszerte, az egyre elterjedtebb diagnosztikájától függetlenül is folyamatosan növekszik [27, 28]. Coeliakia bármely életkorban jelentkezhet, és tünetei meglehetősen széleskörúek lehetnek [24]. Előfordulhat tünetmentesség is [25], de a leggyakrabban a gluténfogyasztást követő, felszívódáshoz köthető tünetek jelennek meg (hasmenés, fogyás vagy növekedési rendellenesség) [20]. A coeliakia extraintestinalis, más szervrendszereket érintő hatása idegrendszeri, cardiovascularis, hepatobiliaris, hematológiai és endokrin rendellenességeket okozhat [24]. Kezeletlenül kevéssé visszafordítható neurológiai károkat okoz, valamint magasabb mortalitási kockázattal jár [24]. Egyetlen ismert és hatásos kezelése a gluténmentes étrend (GMÉ, avagy "gluten-free diet”, GFD) [24].

A coeliakia tünetei és következményei jelentős szenvedést okozhatnak [29], a GMÉ betartása gyakran komoly kihívást jelent az érintett személyeknek [30]. A coeliakiával élő személyek életminőségét befolyásolják a kellemetlen gastrointestinalis tünetek, az ehhez kapcsolódó aggodalmak és szociális terhek is [30]. Whitaker és mtsai [31] kutatásában a coeliakiával élők 68\%-a számolt be arról, hogy kevésbé tudta élvezni az ételeket, 57\%-a szorongott az egészsége miatt, 43\%-a frusztráltságot érzett a diéta miatt, illetve az érintettek 35\%-ának alacsonyabb volt a társadalmi aktivitása. A legmarkánsabb tapasztalat, hogy a coeliakiával élók nagy arányban kerülik a társadalmi eseményeket [32], s föleg a publikus helyen való étkezéstől tartanak, amely számukra feszengéssel és szégyennel társul.

A szégyen egy olyan komplex, alsóbbrendűségi érzéssel, erőtlenséggel és az elrejtőzés iránti vággyal járó negatív érzelem [33], melynek átélése nem ritka a coeliakiások körében, különösen maga a betegség és a speciális étrend miatt [34-36]. A megszégyenülés és/vagy az ettól való félelem pedig stigmatizációt hordoz magában [4]. A stigma megrengeti az érintett személy társas rangját, alsóbbrendűségi érzést válthat ki [37], illetve szégyenérzéssel is jár [38]. Wood és mtsai [39] pszichózissal élók esetében találtak erre empirikus igazolást, miszerint a stigma a szégyen közvetítésével fejtette ki hatását a depresszióra, a reménytelenségre és a pszichózisból való felépülésre. A magasabb stigmatizációs élmény tehát hozzájárulhat a magasabb szégyenélményhez, ami a pszichés jóllét negatív mutatóihoz vezethet.

Számos kutatási eredmény fellelhető a szakirodalomban, amelyek a stigmatizáció és a szégyen szerepét vizsgálták krónikus szomatikus vagy mentális betegséggel élők körében [15, 39-42], azonban coeliakiával élőkkel kapcsolatos eredmények nem állnak rendelkezésünkre. Emellett, jelenlegi tudásunk szerint sem a hazai, sem a nemzetközi szakirodalomban nem történt még kísérlet arra, hogy a stigmatizáció mértékét az SSCI-8 használatával mérjék coeliakiával élők körében.

\section{Célkitüzések}

Kutatásunk fó célja az SSCI-8 magyar adaptációja és az ehhez szükséges pszichometriai vizsgálata volt coeliakiások körében. A kutatás további célja volt megvizsgálni a szégyen közvetítő szerepét a stigmatizáció és a különböző jóllétváltozók kapcsolatában coeliakiások körében.

\section{Módszerek}

\section{Eljárás}

A kutatás egy önbeszámolós kérdőíves, keresztmetszeti vizsgálat keretén belül zajlott, online adatfelvételt alkalmazva. A vizsgálat az etikai kérelem pozitív elbírálása után kezdődött. A kutatást az ELTE PPK Kutatásetikai Bizottsága engedélyezte (az engedély száma: 2020/130). A kutatás során a potenciális résztvevőknek egy online kérdőívcsomagot kellett kitölteniük. A vizsgálatban való részvétel, így a kérdőívek kitöltése teljesen anonim és önkéntes módon történt, minden esetben a Tájékoztató és Beleegyező Nyilatkozat elfogadását követően.

A kutatás hozzáférhetőségi mintavételt alkalmazott. A résztvevők toborzása a közösségi média révén történt. A közösségi média platformjain, különböző gluténérzékenységhez kötődő csoportokban került megosztásra az online kérdőívcsomag linkje és a kutatásban való részvételre való felhívás. 


\section{Résztvevők}

A kutatásban részt vevők 18 éven felüli, pszichiátriai zavarral nem küzdő személyek voltak. A kérdőívet összesen 264-en töltötték ki, s közülük végül 85, orvosilag diagnosztizált coeliakiáról beszámoló személytől érkezett válaszok kerültek be az elemzésbe. Kizárásra kerültek az egyéb gluténérzékenységgel vagy krónikus betegséggel küzdők, valamint a diagnózissal nem rendelkező, önmagukat gluténérzékenynek tartó személyek és a krónikus betegséggel nem küzdő személyek. A coeliakiás kitöltők életkora 18 és 62 év között volt (átlagéletkor 37,64 év, $\mathrm{SD}=11,10), 91,8 \%$-uk nő $(\mathrm{n}=78)$. A coeliakiások körében a diagnózis óta eltelt idó átlaga 9,8 év volt $(\mathrm{SD}=$ $7,61)$.

\section{Méröeszközök}

A kérdő́ivcsomag demográfiai, illetve betegségre vonatkozó adatok gyújtésével indult. Ezt követően az alábbi mérőeszközöket töltötték ki a részt vevő személyek.

\section{8 tételes Stigmatizáció Krónikus Betegségekben Kérdőív (SSCI-8 - Stigma Scale for Chronic Illness-8)}

Az SSCI-8 eredeti változata valid és megbízható mérőeszköznek bizonyult (Cronbach- $\alpha=0,89$ ) [10]. A kérdőív a jelen kutatók tudomása szerint hazánkban még nem volt adaptálva; a fordítói munkát Gondár Vivien Nóra, Illyés Zoltán és Vizin Gabriella végezte Beaton és mtsai [43] ajánlása szerint. A mérőeszköz pszichometriai vizsgálata a jelen kutatás keretein belül történt. A kérdőív 8 tételből tevődik össze, így könnyen alkalmazható klinikai közegben is [10]. Az állításokat (például „Zavarban voltam a betegségemmel kapcsolatban”; „Néhányan úgy viselkedtek velem, mintha az én hibám lenne ez a betegség”) 4 fokú skálán lehet értékelni ( 1 = soha, 4 = mindig); ezekból a kérdőív egyfaktoros struktúrájának megfelelően [10] összpontszám képezhető, mely 8 és 40 pont között terjedhet. Minél magasabb pontszámot ér el rajta valaki, ez annál nagyobb stigmatizáltságot jelez.

\section{Szégyen Élmény Skála \\ (ESS - Experience of Shame Scale)}

Az ESS a krónikus szégyen mérésére szolgáló, 25 tételes kérdőív [33], melynek hazai adaptációját Vizin, Urbán és Unoka [44] végezték. A krónikus szégyent három faktorra bontja: karakterológiai, viselkedési és testi szégyen [45]. A válaszadók az egyes tételeket 4 pontos Likertskálán értékelik ( 1 = egyáltalán nem jellemző, $4=$ nagyon jellemző) [45]. Az észlelt szégyen mértékét a válaszok által adott pontszámok összege adja, mely révén a fent ismertetett három szégyendimenzió mellett egy öszszesített szégyenélményt kifejező összpontszám is számítható. A jelen kutatásban a mérőeszköz belső megbíz- hatósága jónak bizonyult, mind az összpontszám $(\alpha=0,92)$, mind az alskálák tekintetében $(\alpha=0,94-$ $0,86)$.

\section{A WHO Jóllét Kérdőív magyar változata (WBI-5 - WHO Well-Being Index-5)}

A WHO Jóllét Kérdőív [46] rövidített magyar változatát Susánszky és mtsai [47] munkásságának köszönhetjük. $\mathrm{Az}$ öttételes rövid kérdőív a válaszadók közérzetéről gyűjt információt az előző kéthetes időszak alapján. A megítélendő állítások (például „Az elmúlt két hét során érezte magát vidámnak és jókedvűnek?”) négyfokú skálán értékelendők ( 0 = egyáltalán nem jellemző, 3 = jellemző). A kérdőív tételeinek egyike sem fordított: minél nagyobb pontszámot ér el valaki, az annál pozitívabb pszichológiai állapotról számol be. Az állításokra adott válaszok pontszámai 0-tól 3-ig terjedhetnek, így a kérdőíven szerezhető összpontszámok 0 és 15 között mozoghatnak. A jelen kutatásban a méróeszköz megbízhatósága jónak bizonyult $(\alpha=0,82)$.

\section{Coeliakia Életminőség Kérdőív (CDQ - Coeliac Disease Questionnaire)}

A CDQ egy 28 tételes kérdőív, melyben a kitöltő a kérdésekre 1-től 7-ig terjedő skálán válaszolhat [30, 48]. A kérdőív a coeliakiások életminőségét vizsgálja, az öszszesített értéken belül négy faktor mentén: érzelmi és szociális tényezôk, valamint a betegséghez és a kezeléshez kapcsolódó aggodalmak és gyomor-bél rendszeri problémák [30]. Az összesített és az alskálákon jelzett magasabb pontszám jobb életminőséget jelent, ami 28tól 196-ig terjedhet, hiszen a válaszok összegéből adódik, kivéve a 14. kérdésnél, amely egy fordított tétel [30]. A jelen vizsgálatban a mérőeszköz megbízhatósága jónak bizonyult, mind az összpontszám $(\alpha=0,92)$, mind az alskálák tekintetében $(\alpha=0,85-0,74)$.

\section{Statisztikai elemzések}

A jelen tanulmány keretében elvégzett statisztikai elemzések több lépésben kívánták vizsgálni az SSCI-8 strukturális és kritériumvaliditását hazai mintán. Elsőként az elemzések célja az SSCI-8 faktorstruktúrájának és reliabilitásának vizsgálata volt. A skála faktorstruktúráját vizsgáló korábbi nemzetközi tanulmányok eredményei alapján [11-14] a jelen tanulmány megerősítő faktorelemzés alkalmazásával az egyfaktoros struktúra illeszkedésének mértékét tesztelte. A kérdőív tételei több esetben a normális eloszlástól eltérő eloszlási mintázatot mutattak, így az ebből adódó potenciális torzító hatások kontrollálása érdekében a „maximum likelihood” (legnagyobb valószínűség) becslési eljárás normalitástól való eltérésre robusztus (MLR) változatának alkalmazásával történt az egyfaktoros mérési modell paramétereinek megállapítása. A modell illeszkedésének mértéke több mutató 
alapján került megállapításra: komparatív illeszkedési mutató (Comparative Fit Index; CFI), Tucker-Lewisféle illeszkedési mutató (Tucker-Lewis Index; TLI), residuumok átlagos négyzetgyöke (root mean square error of approximation; RMSEA) és standardizált residualis négyzetes középérték (standardized root mean square residual; SRMR). A CFI- és TLI-mutatók esetében a 0,90-es érték alatti, míg az RMSEA és SRMR tekintetében a 0,08 fölötti értékek jelezhetnek nem megfelelő szintű illeszkedést. Továbbá az ún. modifikációs indexek vizsgálata révén a tételek közötti hibakorrelációk, azaz a közös faktor hatásán túl azonosítható tételek közötti egyedi kapcsolatok is elemzésre kerültek. A skála belső reliabilitásának jellemzése Cronbach- $\alpha$ és McDonald- $\omega$ mutatók alapján történt.

Az elemzések következő lépéseként a jelen tanulmány az SSCI-8 kritériumvaliditását vizsgálta. Korrelációs elemzések keretében a krónikus betegségből származó stigmatizáció kapcsolatát a coeliakiás életminőség különböző aspektusaival, a globális jólléttel és a szégyen különböző dimenzióival vizsgáltuk meg. Mivel az egyes skálák esetében nem normális eloszlási mintázat volt tapasztalható, a Pearson-féle korrelációs együtthatók becslése robusztus, „bootstrap ” módszer alkalmazásával történt, 1000 random módon kiválasztott mintán.

Végül két különálló mediációs modell keretében az összesített szégyenélmény potenciális közvetítő szerepét vizsgáltuk a krónikus betegségből származó stigmatizáció és az összesített coeliakiás életminőség között („A” mediációs modell), valamint a krónikus betegségból származó stigmatizáció és a globális jóllét között („B” mediációs modell). Azaz mindkét modellben a krónikus betegségből adódó stigmatizáció volt a distalis prediktor változó és az összesített szégyenélmény a mediátor változó, míg a kimeneti változó tekintetében különbözött a két modellben (összesített coeliakiás életminőség vagy globális jóllét). A két modell külön-külön történő tesztelését az alacsony mintaméret indokolta. Mindkét modellben kontrollálásra került a nem és az életkor hatása. Az összesített szégyenélmény közvetítő szerepének tesztelése és értékelése a krónikus betegségből adódó stigmatizáció és a kimeneti változók közötti indirekt hatásméret-mutatók figyelembevételével történt. A mediációs modellekben szereplő paraméterek becslése robusztus, MLR-eljárással történt a változók normalitástól eltérő eloszlási mintázatai miatt.

A statisztikai elemzések elvégzése az IBM SPSS Statistics 26 (IBM Corporation, Armonk, NY, USA) és az Mplus 8 statisztikai programok felhasználásával történt.

\section{Eredmények}

\section{Megerösitó faktorelemzés}

Az SSCI-8 egyfaktoros struktúrája a különböző illeszkedési mutatók alapján összességében nem mutatott megfelelő mértékü illeszkedést $\left(\chi^{2}[20]=39,01 ; \mathrm{p}=0,007\right.$; RMSEA $[90 \% \mathrm{CI}]=0,106[0,055-0,155] ; \mathrm{CFI}=0,885$; TLI $=0,839 ;$ SRMR = 0,070). Ugyanakkor, a modifikációs indexek alapján a 6 . („Zavarban voltam a betegségemmel kapcsolatban”) és 7. tétel („Zavarban voltam a fizikai korlátozottságaim miatt”) tartalmilag összefügghet, mivel mindkettő az internalizált stigmatizáció jelen-

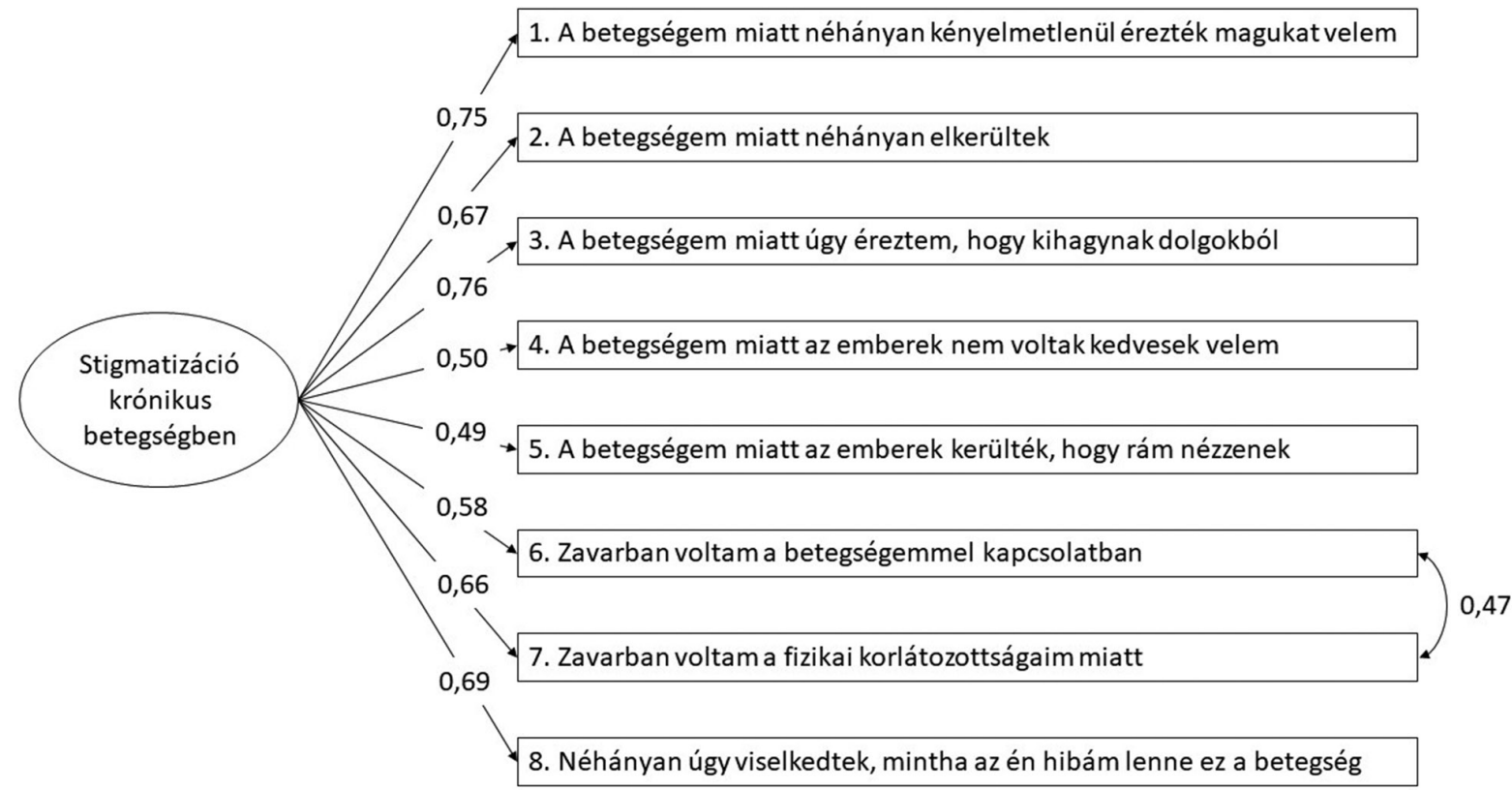

1. ábra

A 8 tételes Stigmatizáció Krónikus Betegségekben Kérdőív egyfaktoros mérési modellje. Az egy irányba mutató nyilakon lévő értékek standardizált faktortöltések $(\lambda)$, míg a két irányba mutató nyílon lévő érték az adott tételek közötti hibakovarianciát (r) fejezi ki. A modellben található összes standardizált faktortöltés és hibakovariancia-érték szignifikáns legalább $\mathrm{p} \leq 0,001$ szinten $\mathrm{n}=85$ 
ségét ragadhatja meg [15] (Daryaafzoon, 2020). Ezáltal a két tétel közötti hibakorreláció engedélyezése indokoltnak volt tekinthető. Az így létrehozott, módosított egyfaktoros modell illeszkedése ezáltal nagymértékben javult a különböző illeszkedési mutatók tekintetében, összességében megfelelő szintú illeszkedéssel volt jellemezhető $\left(\chi^{2}[19]=26,28 ; \mathrm{p}=0,123\right.$; RMSEA [90\% CI] $=0,067[0,000-0,124] ; \mathrm{CFI}=0,956 ; \mathrm{TLI}=0,935$; SRMR $=0,058)$. Az utóbbi mérési modellben található standardizált faktortöltéseket az 1. ábra mutatja be. Az SSCI-8 tételei mérsékelten erős és erős szintű kapcsolatokat mutattak a definiált latens konstruktummal $(\lambda=$ 0,49 és 0,76 között). A skála belső konzisztenciája a Cronbach- $\alpha(0,85)$ és a McDonald- $\omega(0,85)$ mutatók alapján magas szintúnek volt tekinthető.

\section{A kritériumvaliditás vizsgálata}

A módosított, egyfaktoros mérési modellból származó, krónikus betegségből adódó stigmatizációt mérő faktorérték (a latens faktor mentén mutatkozó érték) kapcsolatát a coeliakiás életminőség különböző aspektusaival, a globális jólléttel és a szégyen különböző dimenzióival az 1. táblázat mutatja be. A korrelációs elemzések alapján a krónikus betegségből származó stigmatizáció szignifi-

1. táblázat |A 8 tételes Stigmatizáció Krónikus Betegségekben Kérdőív kritériumvaliditása

\begin{tabular}{ll}
\hline & $\begin{array}{l}\text { A krónikus betegségból } \\
\text { adódó stigmatizáció } \\
\text { faktorértékkel való } \\
\text { korreláció } \\
\mathrm{r}[95 \% \text { CI }]\end{array}$ \\
\hline $\begin{array}{l}\text { Coeliakiás életminőség - Érzelmi } \\
\text { tényezók }\end{array}$ & $-0,42 * * *[-0,58 ;-0,25]$ \\
Coeliakiás életminőség - Szociális & $-0,61^{* * *}[-0,77 ;-0,43]$ \\
tényezók & $-0,44^{* * *}[-0,60 ;-0,26]$ \\
Coeliakiás életminőség - Betegséggel és & \\
kezeléssel kapcsolatos aggodalmak & $-0,30 * *[-0,49 ;-0,10]$ \\
Coeliakiás életminőség - Gastrointesti- & \\
nalis panaszok & $-0,55^{* * *}[-0,68 ;-0,40]$ \\
Összesített coeliakiás életminőség & $-0,40 * * *[-0,57 ;-0,22]$ \\
Globális jóllét & $0,61 * * *[0,44 ; 0,74]$ \\
Karakterológiai szégyen & $0,50 * * *[0,34 ; 0,65]$ \\
Viselkedéses szégyen & $0,44 * * *[0,22 ; 0,63]$ \\
Testi szégyen & $0,60 * * *[0,45 ; 0,74]$ \\
Összesített szégyenélmény &
\end{tabular}

$\mathrm{n}=80$

Az elemzések során a Pearson-féle korrelációs együttható (r) és a kapcsolódó 95\%-os konfidenciaintervallum (95\% CI) becslése „bootstrap” módszer alkalmazásával történt, 1000 random módon kiválasztott mintán.

Szignifikanciaszint: ${ }^{*} \mathrm{p}<0,05 ;{ }^{* *} \mathrm{p}<0,01 ;{ }^{* *} \mathrm{p}<0,001$

$\mathrm{CI}=$ konfidenciaintervallum káns, negatív irányú, és erős kapcsolatot mutatott az öszszesített coeliakiás életminőséggel és a coeliakiás életminőség szociális aspektusaival, illetve szignifikáns, negatív irányú és közepes erősségű kapcsolatot a coeliakiás életminőség érzelmi tényezőivel, a betegséggel és kezeléssel kapcsolatos aggodalmakkal, a gastrointestinalis panaszokkal és a globális jólléttel. Továbbá a krónikus betegségből adódó stigmatizáció szignifikáns, pozitív irányú és erős összefüggésben állt az összesített szégyenélménynyel és a karakterológiai és viselkedéses szégyennel, valamint szignifikáns, pozitív irányú és közepes korreláció volt látható a krónikus betegségből adódó stigmatizáció és a testi szégyen konstruktumai között.

\section{Mediációs elemzések}

A 2. ábrán láthatók a mediációs modellek eredményei, melyek az összesített szégyenélmény közvetítő szerepét vizsgálták a krónikus betegségbőll adódó stigmatizáció és az összesített coeliakiás életminőség között („A” modell), valamint a krónikus betegségból adódó stigmatizáció és a globális jóllét között („B” modell). A modellek szignifikáns, pozitív és erős kapcsolatot jeleztek a krónikus betegségből adódó stigmatizáció és az összesített szégyenélmény között, illetve az összesített szégyenélmény szignifikáns, negatív és közepes összefüggést mutatott az összesített coeliakiás életminőséggel és a globális jólléttel. Ennek megfelelően mindkét modell esetében szignifikáns indirekt hatás volt azonosítható a krónikus betegségből adódó stigmatizáció és a kimeneti változók között az összesített szégyenélményen keresztül („A” modell: $\beta=-0,22 ; \mathrm{p}=0,002 ;, \mathrm{B}$ ” modell: $\beta=-0,22$; $\mathrm{p}=0,004)$. Ugyanakkor fontos kiemelni, hogy a két mediációs modell között eltérés volt megfigyelhető a krónikus betegségből adódó stigmatizáció kimeneti változókra irányuló közvetlen (direkt) hatása tekintetében. Míg a coeliakiás életminőségre vonatkozóan a krónikus betegségboól adódó stigmatizáció közvetlen hatása szignifikáns maradt az összesített szégyenélmény figyelembevételét követően is (negatív irányú és közepes erősségú kapcsolat), addig a globális jóllét tekintetében a krónikus betegségbool adódó stigmatizáció közvetlen hatása nem maradt szignifikáns az összesített szégyenélmény hatásának kontrollálást követően.

\section{Megbeszélés}

Kutatásunk fő célja a krónikus betegségekhez kapcsolódó stigmatizációt mérő, nemzetközileg széles körben használt SSCI-8 hazai adaptációja volt. További cél volt a krónikus betegséggel járó stigmatizáció és a szégyenélmény coeliakiás személyek életminőségére és jóllétére kifejtett hatásának vizsgálata.

Az SSCI-8 faktorelemzése során az unidimenzionális modell megfelelő illeszkedést mutatott magas belső konzisztenciaértékek mellett, ami megfelel korábbi szakirodalmi eredményeknek más krónikus betegséggel jelle- 

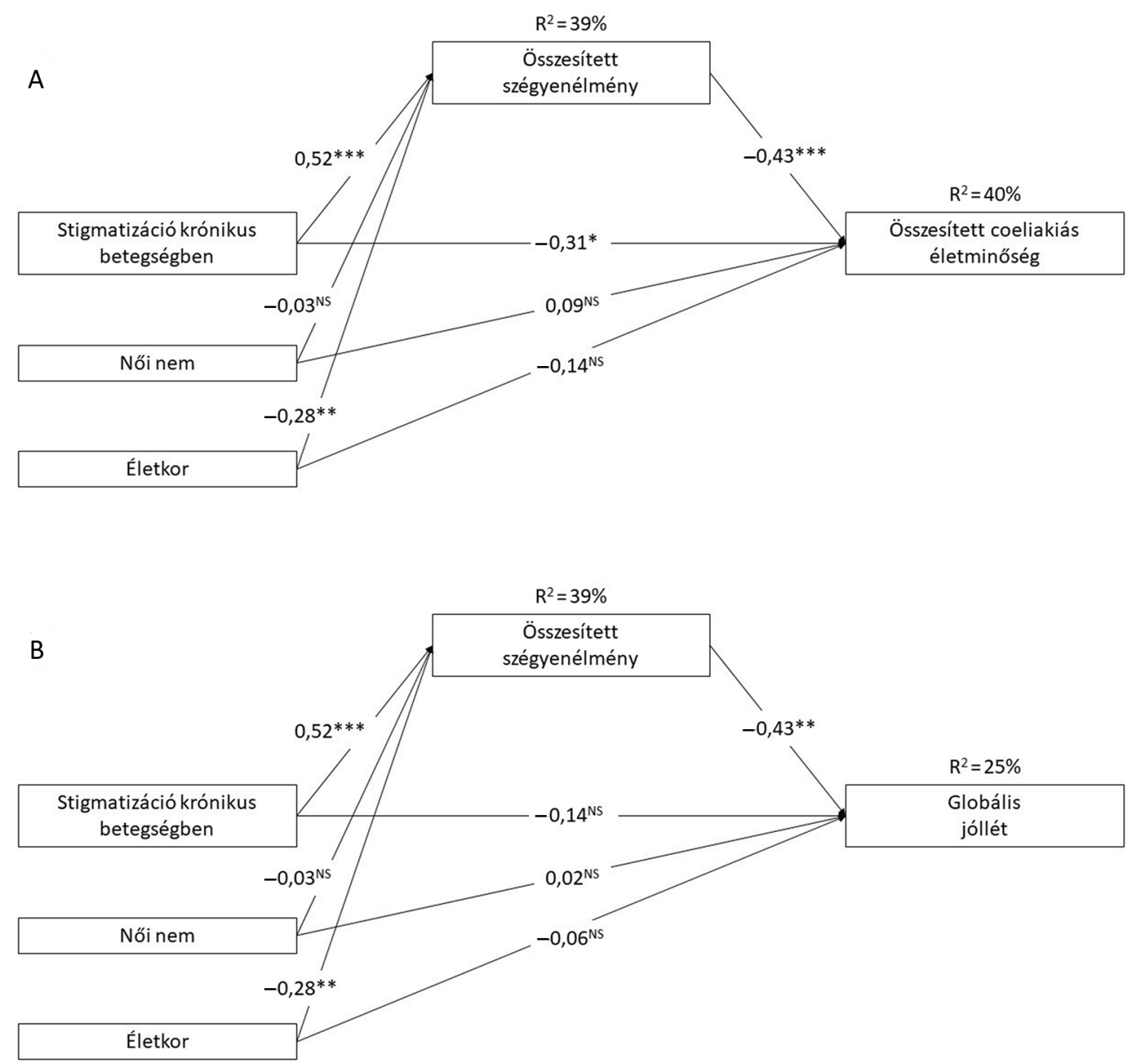

2. ábra

Mediációs modellek a szégyen közvetítő szerepének vizsgálatára a krónikus betegségbool adódó stigmatizáció és az összesített coeliakiás életminőség között (A), valamint a krónikus betegségből adódó stigmatizáció és a globális jóllét között (B)

A nyilakon található értékek standardizált regressziós együtthatók $(\beta)$. Szignifikanciaszint: NS p $>0,05\left(\right.$ nem szignifikáns); ${ }^{*} \mathrm{p}<0,05 ;{ }^{* *} \mathrm{p}<0,01$; $\star * * \mathrm{p}<0,001$

mezhető populációkon vizsgálva [10-13]. A jelen kutatás faktoranalitikus és reliabilitási eredményei arra utalnak, hogy az SSCI-8 a stigmatizációt átfogóan mérő skála, melynek összpontszáma megbízható mérést nyújthat a krónikus betegségből adódó stigmatizáció mérésére coeliakiások körében. Kritériumvaliditását megerősítik a jelen korrelációs elemzések eredményei, melyek szerint a krónikus betegségből adódó stigmatizáció a coeliakiás életminőség szociális tényezőkre vonatkozó alskálájával mutatta az egyedüli erős, negatív irányú együttjárást a többi alskálával látható közepes erősségű korrelációkhoz képest. Tehát a jelen vizsgálat eredményei is megerősítik azon korábbi eredményeket, miszerint a stigmatizáció csökkent életminőséggel jár együtt [6], ahogy a korábbi, szociális nehézségeket hangsúlyozó kutatásokat is [34, 35], amelyekben többek között beszámoltak társasági étkezéssel járó feszengésról és szégyenről [32], valamint ebből adódó alacsonyabb társadalmi aktivitásról [31] és/ vagy a diéta megszegéséról [17].
A kutatás új empirikus adatokon alapuló kapcsolatot talált coeliakiások körében a szégyen és a stigma között, melyről eddig csak kvalitatív kutatási adatok álltak rendelkezésre [19, 32, 34]. A tanulmány által tesztelt mediációs modellek szerint a magasabb stigmatizációs élmény magasabb szégyenélményhez járulhat hozzá, ami a pszichés jóllét (coeliakiás életminőség, globális jóllét) csökkenését okozhatja. Ezen eredmény egybecseng Wood és mtsai [39] eredményeivel, akik szintén azt találták, hogy a magasabb stigmatizációs élmény hozzájárult a magasabb szégyenélményhez, ami a pszichés jóllét negatív mutatóihoz vezetett pszichózisból felépülők körében (például depresszió, reménytelenség), tehát a szégyen közvetítő hatása volt azonosítható a stigmatizáció és a pszichés statust mérő különböző változók között. A tesztelt mediációs modellekben a krónikus betegséggel járó stigmatizáció szignifikáns direkt hatása volt megfigyelhető a coeliakiás életminőségre a szégyen hatása mellett, míg a stigmatizáció szignifikáns direkt hatása nem volt azonosítható ugyanígy a globális jóllétre. Ez 
tovább hangsúlyozza az SSCI-8 érvényességét, hiszen a krónikus betegségből adódó stigmatizáció szorosabban együtt jár a coeliakiás életminőséggel (például gastrointestinalis panaszok, betegséggel kapcsolatos aggodalmak stb.), mint a globális jólléttel (például a résztvevő mennyire érezte magát vidámnak, jókedvünek, aktívnak, élénknek).

$\mathrm{Az}$ eredmények értelmezésekor fontos figyelembe venni a kutatás limitációit. A kutatás egyik fó limitációja az alacsony elemszám. A hozzáférhetőségi mintavétel révén, illetve tekintettel arra, hogy gluténérzékenységgel kapcsolatos csoportokban történt az adatgyưjités, a jelen kutatásban gyứjtött mintából csak korlátozottan szabad következtetéseket levonni a hazai coeliakiás populációra (például lehet, hogy a motiváltabb betegek inkább kitöltötték a kérdőívet; vagy például a nők nagyon magas aránya miatt a férfi coeliakiásokat kevésbé reprezentálja a jelen kutatás). További limitáció, hogy a résztvevők kiválasztása nem objektív, hanem önbeszámolón alapuló adatokra támaszkodott. A keresztmetszeti elrendezésból adódóan az ok-okozati viszonyokra a változók között nem lehet következtetni, így nem lehet kizárni a kétirányú kapcsolatokat a változók között (például hogy nem a stigmatizáció jósolja meg a szégyent vagy a coeliakiás életminőséget, hanem épp fordítva történik a hatás). Továbbá az adatgyứjtés a COVID-19-pandémia első hullámával, illetve az annak visszaszorítására hozott intézkedésekkel esett egybe: néhány kitöltő jelezte is, hogy nagyban befolyásolhatta a válaszaikat. Ez különösen fontos lehetett például a jóllét felmérésének eredményeire, hiszen ott az előző két hét általános közérzetére irányultak a kérdések.

\section{Következtetés}

A jelen vizsgálatban egy nemzetközi szinten széles körben alkalmazott stigmatizációs kérdőív adaptálására került sor, mely hazai krónikus betegekkel végzett kutatásokban és az egészségügyi ellátás gyakorlatában is hasznos mérőeszköz lehet. Továbbá a kutatás empirikus adatokkal támasztja alá, hogy a stigmatizáció a szégyen közvetítő hatásán keresztül fontos szerepet tölthet be a coeliakiás életminőség és a globális jóllét magyarázatában. Az eredmények rávilágítanak arra, hogy a stigmatizáció és a szégyenélmény további kutatása szükséges, különösen a hatékony pszichoszociális intervenciók kifejlesztését megcélozva. Hatékony pszichológiai segítség révén a szégyen és a stigmatizáltság mérséklésével a coeliakiával élők életminősége, valamint fizikai és lelki állapotuk javulhat, ami a GMÉ betartása révén számottevően hozzájárulhat a betegség okozta súlyos tünetek és szövődmények elkerüléséhez, így a népegészségügyi kockázatok mérséklődéséhez is.
Anyagi támogatás: A közlemény megírásáért és a kapcsolódó kutatómunkáért Sz. H. és V. G. anyagi támogatásban nem részesült. H. Zs. a Nemzeti Kutatási, Fejlesztési és Innovációs Hivatal által támogatott Tématerületi Kiválósági Program 2020 - Intézményi Kiválósági Alprogram (TKP2020-IKA-05) támogatásában, illetve az Innovációs és Technológiai Minisztérium ÚNKP-203 és ÚNKP-21-4 kódszámú Új Nemzeti Kiválóság Programjának a Nemzeti Kutatási, Fejlesztési és Innovációs Alapból finanszírozott szakmai támogatásában részesült.

Szerzői munkamegosztás: Sz. H.: Konceptualizálás, a vizsgálat lebonyolítása, adatkezelés, módszertan, az eredeti kézirat megírása, a kézirat szerkesztése és véleményezése. H. Zs.: Konceptualizálás, az adatok kezelése, módszertan, statisztikai elemzés, a kézirat szerkesztése és véleményezése. V. G.: Konceptualizálás, módszertan, szupervízió, a kézirat szerkesztése és véleményezése. A cikk végleges változatát valamennyi szerző elolvasta és jóváhagyta.

Érdekeltségek: A szerzőknek nincsenek érdekeltségeik.

\section{Irodalom}

[1] Weiss MG, Ramakrishna J, Somma D. Health-related stigma: rethinking concepts and interventions. Psychol Health Med. 2006; 11: 277-287.

[2] Leventhal H, Halm E, Horowitz C, et al. Living with chronic illness: a contextualized, self-regulation approach. In The Sage Handbook of Health Psychology, Sage, 2005; pp. 197-240.

[3] Earnshaw VA, Smith LR, Chaudoir SR, et al. HIV stigma mechanisms and well-being among PLWH: a test of the HIV stigma framework. AIDS Behav. 2013; 17: 1785-1795.

[4] Goffman E. Stigma and social identity. In: Anderson T. (ed.) Understanding deviance: connecting classical and contemporary perspectives. Routledge, New York, NY, 1963; pp. 256-265.

[5] Brohan E, Slade M, Clement S, et al. Experiences of mental illness stigma, prejudice and discrimination: a review of measures. BMC Health Serv Res. 2010; 10: 80.

[6] Kane JC, Elafros MA, Murray SM, et al. A scoping review of health-related stigma outcomes for high-burden diseases in lowand middle-income countries. BMC Med. 2019; 17: 17.

[7] Zelaya CE, Sivaram S, Johnson SC, et al. Measurement of self, experienced, and perceived HIV/AIDS stigma using parallel scales in Chennai, India. AIDS Care 2012; 24: 846-855.

[8] Wiener J, Malone M, Varma A, et al. Children's perceptions of their ADHD symptoms: positive illusions, attributions, and stigma. Can J Sch Psychol. 2012; 27: 217-242.

[9] Hungarian Central Statistical Office. Chronic diseases by age group. [Központi Statisztikai Hivatal. Krónikus betegségek korcsoport szerint.] 2019. Available from: http://www.ksh.hu/ docs/hun/xstadat/xstadat_eves/i_ege0035b.html?down= 646.4000244140625 [accessed: May 20, 2021]. [Hungarian]

[10] Molina Y, Choi SW, Cella D, et al. The stigma scale for chronic illnesses 8-item version (SSCI-8): development, validation and use across neurological conditions. Int J Behav Med. 2013; 20: $450-460$.

[11] Yoo SH, Kim SR, So HS, et al. The validity and reliability of the Korean version of the Stigma Scale for Chronic Illness 8-items 
(SSCI-8) in patients with neurological disorders. Int J Behav Med. 2017; 24: 288-293.

[12] Scott W, Yu L, Patel S, et al. Measuring stigma in chronic pain: preliminary investigation of instrument psychometrics, correlates, and magnitude of change in a prospective cohort attending interdisciplinary treatment. J Pain 2019; 20: 1164-1175.

[13] Ballesteros J, Martínez-Ginés ML, García-Domínguez JM, et al. Assessing stigma in multiple sclerosis: psychometric properties of the Eight-Item Stigma Scale for Chronic Illness (SSCI-8). Int J MS Care 2019; 21: 195-199.

[14] Lu Q, Deng C, Fu L, et al. Reliability and validity of a Chinese version of the Stigma Scale for Chronic Illness (SSCI) in patients with stroke. Top Stroke Rehabil. 2019; 26: 312-317.

[15] Daryaafzoon M, Amini-Tehrani M, Zohrevandi Z, et al. Translation and factor analysis of the Stigma Scale for Chronic llnesses 8 -item version among Iranian women with breast cancer. Asian Pac J Cancer Prev. 2020; 21: 449-455.

[16] Van Brakel WH. Measuring health-related stigma: a literature review. Psychol Health Med. 2006; 11: 307-334.

[17] Olsson C, Lyon P, Hörnell A, et al. Food that makes you different: the stigma experienced by adolescents with celiac disease. Qual Health Res. 2009; 19: 976-984.

[18] Schroeder RD, Mowen TJ. "You Can't Eat WHAT?" Managing the stigma of celiac disease. Deviant Behav. 2014; 35: 456-474.

[19] Horn AJ. An exploration of diagnosis and illness experiences of women and men living with celiac disease. Master's Thesis, Indiana University, Bloomington, IN, 2017.

[20] Ludvigsson JF, Leffler DA, Bai JC, et al. The Oslo definitions for coeliac disease and related terms. Gut 2013; 62: 43-52.

[21] Cabanillas B. Gluten-related disorders: celiac disease, wheat allergy, and nonceliac gluten sensitivity. Crit Rev Food Sci Nutr. 2020; 60: 2606-2621.

[22] Sapone A, Bai JC, Ciacci C, et al. Spectrum of gluten-related disorders: consensus on new nomenclature and classification. BMC Med. 2012; 10: 13

[23] Dale HF, Biesiekierski JR, Lied GA. Non-coeliac gluten sensitivity and the spectrum of gluten-related disorders: an updated overview. Nutr Res Rev. 2019; 32: 28-37.

[24] Fedor I, Zöld É, Barta Z. The extraintestinal spectrum of gluten sensitivity. [A gluténérzékenység extraintestinalis spektruma.] Orv Hetil. 2019; 160: 1327-1334. [Hungarian]

[25] Lindfors K, Ciacci C, Kurppa K, et al. Coeliac disease. Nat Rev Dis Primers 2019; $5: 3$.

[26] Briani C, Samaroo D, Alaedini A. Celiac disease: from gluten to autoimmunity. Autoimmun Rev. 2008; 7: 644-650.

[27] Gibson PR. Commentary: recognising the boom in coeliac disease prevalence was more than just increased awareness. Aliment Pharmacol Ther. 2020; 51: 207-208.

[28] Singh P, Makharia GK. Food allergy and food hypersensitivity. In: Rao SS, Lee YY, Ghoshal UC. (eds.) Clinical and basic neurogastroenterology and motility. Academic Press, London, 2020; pp. 387-395

[29] Rigó A. Coeliac disease in biopsychosocial approach. [A lisztérzékenység biopszichoszociális szemléletủ áttekintése.] Mentalhig Pszichoszom. 2013; 14: 167-199. [Hungarian]

[30] Rigó A, Nagy D, Bíró M, et al. Quality of life in coeliac disease. [Életminőség lisztérzékenységben.] Alk Pszichol. 2014; 14: 117-131. [Hungarian]

[31] Whitaker JK, West J, Holmes GK, et al. Patient perceptions of the burden of coeliac disease and its treatment in the UK. Aliment Pharmacol Ther. 2009; 29: 1131-1136.

[32] Silvester JA, Weiten D, Graff LA, et al. Living gluten-free: adherence, knowledge, lifestyle adaptations and feelings towards a gluten-free diet. J Hum Nutr Diet. 2016; 29: 374-382.
[33] Andrews B, Qian M, Valentine JD. Predicting depressive symp toms with a new measure of shame: the Experience of Shame Scale. Br J Clin Psychol. 2002; 41: 29-42.

[34] Solomon Y, McClinchy J. Dining out with coeliac disease: an analysis of online message board postings on the social implications and the challenges to live a normal life. Eur J Nutr Food Saf. 2014; 4: 202-203.

[35] Sverker A, Hensing G, Hallert C. 'Controlled by food' - lived experiences of coeliac disease. J Hum Nutr Diet. 2005; 18: 171180.

[36] Trindade IA, Duarte J, Ferreira C, et al. The impact of illnessrelated shame on psychological health and social relationships: testing a mediational model in students with chronic illness. Clin Psychol Psychother. 2018; 25: 408-414.

[37] Birchwood M, Trower P, Brunet K, et al. Social anxiety and the shame of psychosis: a study in first episode psychosis. Behav Res Ther. 2007; 45: 1025-1037.

[38] Gilbert L, Walker L. 'My biggest fear was that people would reject me once they knew my status...': stigma as experienced by patients in an HIV/AIDS clinic in Johannesburg, South Africa. Health Soc Care Community 2010; 18: 139-146.

[39] Wood L, Byrne R, Burke E, et al. The impact of stigma on emotional distress and recovery from psychosis: the mediatory role of internalised shame and self-esteem. Psychiatry Res. 2017; 255: 94-100.

[40] Rüsch N, Corrigan PW, Heekeren K, et al. Well-being among persons at risk of psychosis: the role of self-labeling, shame, and stigma stress. Psychiatr Serv. 2014; 65: 483-489.

[41] Schibalski JV, Müller M, Ajdacic-Gross V, et al. Stigma-related stress, shame and avoidant coping reactions among members of the general population with elevated symptom levels. Compr Psychiatry 2017; 74: 224-230.

[42] Williamson TJ, Ostroff JS, Haque N, et al. Dispositional shame and guilt as predictors of depressive symptoms and anxiety among adults with lung cancer: the mediational role of internalized stigma. Stigma Health 2020; 5: 425-433.

[43] Beaton DE, Bombardier C, Guillemin F, et al. Guidelines for the process of cross-cultural adaptation of self-report measures. Spine 2000; 25: 3186-3191.

[44] Vizin G, Urbán R, Unoka Zs. Shame, trauma, temperament and psychopathology: construct validity of the Experience of Shame Scale. Psychiatry Res. 2016; 246: 62-69.

[45] Vizin G. The role of shame in mental disorders. PhD-thesis. [A szégyen szerepe a mentális zavarokban. Doktori disszertáció.] Semmelweis Egyetem, Mentális Egészségtudományok Doktori Iskola, Budapest, 2018. [Hungarian]

[46] Bech P, Gudex C, Johansen KS. The WHO (Ten) Well-Being Index: validation in diabetes. Psychother Psychosom. 1996; 65: 183-190.

[47] Susánszky É, Konkolÿ Thege B, Stauder A, et al. Validation of the short (5-item) version of the WHO Well-Being Scale based on a Hungarian representative health survey (Hungarostudy 2002). [A WHO Jól-lét Kérdoóív rövidített (WBI-5) magyar változatának validálása a Hungarostudy 2002 országos lakossági egészségfelmérés alapján.] Mentalhig Pszichoszom. 2006; 7 : 247-255. [Hungarian]

[48] Häuser W, Gold J, Stallmach A, et al. Development and validation of the Celiac Disease Questionnaire (CDQ), a disease-specific health-related quality of life measure for adult patients with celiac disease. J Clin Gastroenterol. 2007; 41: 157-166.

(Szőcs Henrietta,

Budapest, Izabella u. 46., 1064 e-mail: szocs.henrietta@ppk.elte.hu)

A cikk a Creative Commons Attribution 4.0 International License (https://creativecommons.org/licenses/by/4.0/) feltételei szerint publikált Open Access közlemény, melynek szellemében a cikk bármilyen médiumban szabadon felhasználható, megosztható és újraközölhetö, feltéve, hogy az eredeti szerző és a közlés helye, illetve a CC License linkje és az esetlegesen végrehajtott módosítások feltüntetésre kerülnek. (SID_1) 